\title{
PENGETAHUAN MERESPON BENCANA DALAM KEARIFAN LOKAL
}

\author{
Knowledges within Local Wisdoms for Disaster Response
}

\author{
Ismet Belgawan Harun
}

\author{
Tim Ahli Cagar Budaya, Jawa Barat \\ Program Studi Arsitektur, Institut Teknologi Bandung (Purnabakti) \\ Program Studi Arsitektur, Institut Teknologi Sumatera, Lampung \\ Program Studi Arsitektur, Universitas Persada Indonesia -YAI, Jakarta \\ E-mail: ismetbh@gmail.com
}

\begin{abstract}
Local wisdom is a bundle of local knowledge, living spirit, and activities in a community to face challenges in their life, including in response to disasters. Measures and efforts to respond to disasters as local wisdom take their forms into the intangible (such as norms, values, organizations, behaviors) and tangible ones (such as technologies, design, activities, actions). Behind every measure or effort to cope with disasters as local wisdom, there is its formative knowledge. To apply this measure or effort for responding to the disaster in a wider and contemporary context does not merely replicate the measure or effort, but has to retrieve its formative knowledge and transform the knowledge into a piece of explicit and general knowledge since one particular disaster-related measure or effort is only contextual to its origin. However, not all measures and efforts from local wisdom, especially those of the intangible ones, have explicit knowledge, which is relatively easy to retrieve and transform, since most of the knowledge is embedded in nature. This paper tries to discuss this issue if local wisdom for disaster response is to be applicable for the contemporary and wider context.
\end{abstract}

Keywords: local wisdom, intangible measures/efforts, tangible measures/efforts, explicit knowledge, embedded knowledge, knowledge retrieval, knowledge transformation

\begin{abstract}
Abstrak
Kearifan lokal adalah suatu himpunan pengetahuan, semangat, dan aktifitas dalam suatu masyarakat untuk menghadapi berbagai tantangan dalam kehidupan suatu masyarakat, termasuk dalam menghadapi bencana alam. Cara dan upaya dari suatu kearifan lokal untuk merespon bencana memiliki berbagai bentuknya, baik yang tak teraga seperti norma/aturan, nilai, organisasi, dan perilaku; maupun yang teraga seperti teknologi, desain, aktifitas, dan tindakan. Di balik setiap cara atau upaya ini, terkandung pengetahuan yang bisa dipelajari untuk diterapkan di tempat lain. Namun demikian, untuk menerapkannya dalam lingkup yang lebih luas dan kekinian tidak sekedar mereplikasi cara atau upaya kearifan lokal persis seperti yang dilakukan oleh masyarakat lokal tersebut. Diperlukan penyingkapan terlebih dahulu pengetahuan yang terkandung di dalam kearifan lokal tersebut dan ditransformasikan menjadi pengetahuan eksplisit yang bersifat umum. Ini dikarenakan suatu cara atau upaya tertentu berasal dari kearifan lokal bersifat dan berlingkup lokal. Tidak seluruh cara dan upaya dari suatu kearifan lokal, terutama yang berbentuk tak teraga, memiliki pengetahuan eksplisit yang mudah disingkap dan ditransformasi karena pengetahuan yang dikandungnya bersifat embedded. Makalah ini mencoba berdiskusi di seputar isu ini, yaitu apabila kearifan lokal dalam merespon bencana ingin diterapkan dalam lingkup yang lebih luas dan kekinian.
\end{abstract}

Kata kunci: kearifan lokal, cara/upaya tak teraga, cara/upaya teraga, pengetahuan eksplisit, pengetahuan embedded, penyingkapan pengetahuan, transformasi pengetahuan 


\section{PENDAHULUAN}

\section{Kearifan Lokal dan kebencanaan}

Kearifan pada suatu tradisi, atau kearifan lokal, adalah pengetahuan, etos hidup, dan pengelolaan kehidupan yang diimplementasikan dalam berbagai kegiatan masyarakatnya untuk menghadapi sekaligus menyelesaikan beberapa tantangan agar kebutuhan hidup masyarakatnya dapat dipenuhinya.

Kearifan lokal berkembang dari sistem pengetahuan dan pengelolaan tradisional dan berkembang dari akumulasi pengetahuan dan pola berpikir yang memiliki nilai-nilai kearifan yang telah mengakar dalam budaya suatu masyarakat tradisional, dan diperoleh melalui perjalanan waktu yang cukup lama (Mitchell, Setiawan, dan Rahmi, 2004). Kearifan lokal diwujudkan dalam aktivitas yang dilakukan oleh masyarakat lokal/tertentu dalam menjawab berbagai masalah dalam pemenuhan kebutuhan mereka. Demikian pula, kearifan lokal ada yang terkait dengan merespon berbagai bencana, termasuk bencana alam, dan mengurangi dampak-dampaknya. Berbagai penelitian telah menunjukkan bahwa upaya-upaya merespon bencana berbasis kearifan lokal ini telah mengambil berbagai bentuknya, yang dapat digolongkan ke dalam tiga golongan yang saling berkaitan.

Golongan pertama adalah berupa pengetahuan untuk menghindari bencana yang dimiliki oleh semua unsur dalam masyarakatnya yang diwarisi secara turun-temurun. Pengetahuan ini beragam, seperti cara membangun, cara bercocok tanam, menghindari suatu situasi yang dapat berdampak bencana, dan sebagainya.

Bentuk kedua adalah jenis aktivitas atau tindakan masyarakat yang bersifat langsung merespon bencana, baik yang bersifat individual maupun dalam bentuk kelompok, misalnya adalah membuat tanggul penahan longsor. Atau menanam pohon keras untuk menggantikan pohon keras yang diambil kayunya sehingga fungsi-fungsi pencegahan longsor dapat dipertahankan.

Bentuk ketiga adalah berupa instrumen budaya yang mengatur masyarakat dalam melakukan berbagai aktifitas untuk menghindari bencana. Tabu, sebagai contoh, adalah suatu instrumen untuk mengatur kegiatan atau perilaku masyarakat (agar terhindar dari bencana). Atau, pengaturan zona kegiatan yang sering dijumpai di suatu permukiman tradisional/adat adalah suatu instrumen untuk mengatur kegiatan-kegiatan yang dijalankan agar sensitif terhadap potensi bencana.

Pada umumnya, suatu kearifan lokal adalah kontekstual terhadap lokalitas yang bersangkutan, karena kondisi lokalitas dan permasalahan yang dihadapi oleh kearifan lokal itu spesifik. Dengan demikian, apabila penyelesaian untuk suatu masalah dalam konteks yang bersifat luas hendak mengaplikasikan suatu kearifan lokal tertentu, maka persoalannya bukan pada mengaplikasikannya begitu saja, tetapi adalah pada menyingkap (retrieving) pengetahuan yang terdapat di dalam suatu kearifan lokal untuk dapat digeneralisasi bagi pembelajaran dan untuk aplikasinya yang bersifat luas dan kekinian. 


\section{PEMBAHASAN}

\section{Antara Kepercayaan dan Pengetahuan dalam Kearifan Lokal Kebencanaan}

Kepercayaan dan pengetahuan adalah dasar dari seluruh jenis upaya atau respon dalam menghadapi bencana. Upaya-upaya ini dapat berupa teknologi, tindakan, aktifitas, cara hidup, dan organisasi yang tepat. Di "dalam” setiap jenis upaya ini melekat pengetahuan tentang bagaimana suatu upaya berfungsi merespon bancana. Dalam kaitan ini, bagi suatu kearifan lokal kebencanaan, ada yang menjalankannya sebagai suatu kepercayaan karena secara turun-temurun selalu dijalankan, namun ada masyarakat yang melakukannya dengan dasar pengetahuan sehingga mengerti mengapa yang dijalankannya dapat mengatasi suatu bencana. Kepercayaan atau pengetahuan sendiri masing-masing adalah bagian (subset) dari kerangka yang lebih besar, yaitu sistem kepercayaan (Wayne, 2017). Baik kepercayaan maupun pengetahuan adalah tentang "apa yang benar". Akan tetapi, di antara keduanya terdapat perbedaan.

Kepercayaan adalah tentang apa yang dimengerti atau yang dianggap "benar" walaupun belum tentu sesungguhnya benar. Kepercayaan bukanlah tentang pilihan, karena merupakan sesuatu yang diterima "begitu saja". Percaya adalah sikap atau tindakan (yang bisa bersifat) "tidak sukarela", yang muncul atau dilakukan karena ada bukti yang bisa diterima, walaupun bukti tersebut bersifat personal, bukan "ilmiah". Sedangkan pengetahuan sebagai bagian dari sistem kepercayaan, memiliki bukti "ilmiah" tentang "apa yang benar". Dengan demikian, pengetahuan adalah sebagian dari sistem kepercayaan tentang yang "memang benar". Oleh karenanya, pengetahuan dapat didefinisikan sebagai kepercayaan tentang "yang benar" karena didukung bukti yang bisa dimengerti.

Merespon bencana karena suatu "kepercayaan" adalah karena pelakunya menerima bahwa upaya tertentu yang dilakukannya adalah suatu kebenaran walau tanpa bukti pengetahuan, kecuali bukti bahwa bencana memang tidak pernah terjadi.

Kepercayaan dalam kebencanaan sebagai suatu kearifan lokal biasanya diperoleh dari suatu pewarisan tradisi atau kebiasaan yang berjalan secara turun menurun sehingga tidak dipertanyakan lagi.

Percaya terhadap sesuatu dapat berarti kesadaran terhadap "sesuatu yang benar" adalah rendah, karena sesuatu yang benar ini diterima begitu saja. Sebaliknya, kebenaran yang dipahami karena berdasarkan pengetahuan berarti kesadaran terhadap "sesuatu yang benar" adalah tinggi. Apabila pengetahuan bertambah terhadap "sesuatu yang benar", kesadaran terhadap "sesuatu yang benar" ini berarti juga makin tinggi. Pengetahuan yang dimiliki seseorang atau kelompok adalah suatu keakraban (familiarity), kesadaran, dan/atau pemahaman terhadap seseorang atau sesuatu sebagai fakta, keahlian, atau obyek (Wayne, 2017). Merespon bencana yang didasarkan pengetahuan adalah karena sadar bahwa suatu upaya merespon bencana adalah sesuatu "yang benar", karena (dapat) mengerti penjelasan tentang (kemampuan) upaya ini dalam merespon bencana.

Walaupun demikian, upaya merespon bencana yang didasarkan pada kepercayaan bukan berarti tanpa pengetahuan. Masalah mengetahui pengetahuan di 
dalam upaya tersebut terletak pada mudah-tidaknya menstrukturkan bentuk pengetahuan pembentuk upaya merespon bencana yang berdasarkan kepercayaan tersebut. Upayaupaya merespon bencana yang dijalankan karena kepercayaan mungkin dikarenakan pengetahuan yang membentuknya tidak mudah diakrabi dan dimengerti sehingga tidak mudah distrukturkan dengan jelas untuk memberikan kesadaran di dalam menjalankannya. Dalam kaitan ini, dari sudut bentuknya, pengetahuan dapat dikategorikan ke dalam tiga golongan: (1) pengetahuan eksplisit, (2) pengetahuan implisit (implicit knowledge), dan (3) pengetahuan yang embedded.

Pengetahuan eksplisit adalah pengetahuan yang sudah memiliki (atau mudah diketahui) strukturnya atau sudah (atau mudah) di"kodifikasi" sehingga bisa dipelajari oleh orang lain (misal, sudah berupa teori, menunjukkan logika yang jelas, atau berupa prosedur dan panduan tertentu). Dengan pengetahuan eksplisit, orang mudah mengidentifikasi, menyimpan, dan menggunakannya (Wellman, 2009). Pengetahuan yang sudah tereksplisitkan memungkinkan penggunaannya dalam berbagai konteks lain, termasuk dalam upaya-upaya merespon bencana. Kebanyakan upaya atau cara menghadapi bencana yang berbentuk pengetahuan eksplisit ini adalah yang bersifat teraga dan teknis serta kodifikasinya dapat dilakukan oleh masyarakat ilmiah masa kini sehingga logika dan rasionalitas dari pengetahuan ini mudah untuk dipelajari dan digunakan pada konteks lain di luar lingkungan upaya atau cara yang bersangkutan berasal.

Pengetahuan implisit (atau tacit knowledge) adalah pengetahuan yang melekat pada suatu pengalaman, praktek, atau keahlian tertentu. Pengetahuan jenis ini diperoleh secara sederhana, alami, dan tanpa proses sadar/disengaja, sehingga tidak mudah dijelaskan kembali kepada pihak lain. Atau bahkan orang tidak menyadari bahwa mereka memiliki pengetahuan ini (Chugh, 2015). Pengalihan pengetahuan golongan ini dari orang ke orang membutuhkan kontak personal yang ekstensif dan regular, serta membutuhkan rasa saling percaya. Pengalihan pengetahuan membutuhkan hubungan atau jaringan sosial. Contoh dari pengetahuan ini adalah kemampuan bicara bahasa asing yang didapat ketika mempraktekannya bersama seorang native, atau mendapatkan kemampuan pertukangan karena membantu seorang tukang ahli dalam waktu lama.

Pengetahuan embedded, adalah pengetahuan yang "tertanam" di dalam proses, produk, kebiasaan, budaya, atau struktur (atau obyek tertentu). Sebagai contoh, pengetahuan yang membentuk suatu kebiasaan yang memberikan manfaat tertentu disebut sebagai suatu pengetahuan embedded apabila tidak bisa diuraikan struktur pengetahuannya dan tidak dapat dijelaskan mengapa dapat memberikan manfaat tersebut. Namun kebiasaan ini dapat disusun panduan pelaksanaannya sehingga panduan ini menjadi suatu bentuk pengetahuan eksplisit (karena tercatat) yang bisa diikuti untuk dijalankan agar manfaatnya dapat diraih. Namun demikian, pengetahuan sesungguhnya, yaitu tentang logika keberfungsian dari kebiasaan tersebut tetap bersifat embedded apabila belum teruraikan secara ilmiah. Jadi, perlu dibedakan antara panduan melaksanakan suatu kebiasaan sebagai suatu pengetahuan eksplisit dan pengetahuan 
yang bersifat embedded yang menjadi kerangka pengetahuan substantif dari suatu kebiasaan!

Pengetahuan embedded adalah bentuk yang tidak mudah dikodifikasi, terutama apabila mengenai suatu wujud yang tidak teraga (misal: kebiasaan, organisasi, proses). Ini yang mungkin menjelaskan mengapa banyak berbagai upaya tak teraga dari kearifan lokal di dalam merespon bencana didasarkan pada kepercayaan. Namun demikian, suatu pengetahuan embedded tetap memiliki kemungkinan untuk dibedah dan diketahui agar dapat diketahui pengetahuan eksplisitnya.

Makalah ini mencoba untuk membahas beberapa kasus kearifan lokal dalam pencegahan bencana dari berbagai lokalitas, dengan tujuan untuk mengidentifikasi bentuk-bentuk pengetahuan (bukan substansi pengetahuannya!) yang terkandung di dalamnya. Berdasarkan pemahaman tentang bentuk pengetahuan yang dikandung di dalam kasus-kasus kearifan lokal kebencanaan ini, makalah ini mencoba untuk memberikan catatan, bagaimana pengetahuan-pengetahuan yang berlaku spesifik pada setiap kasus dapat digunakan untuk penggunaannya yang bersifat lebih umum dan luas.

Beberapa kasus kearifan lokal dalam kebencanaan digunakan untuk pembahasan dalam makalah ini, dengan memilih kasus-kasus upaya-upaya merespon bencana yang berbeda, yaitu dari kasus upaya yang bersifat tak teraga sampai dengan yang teraga. Bahan tentang pengalaman dari kasus-kasus ini menggunakan bahan sekunder, yaitu hasil-hasil penelitian para peneliti lain yang telah dipublikasikan.

\section{Kasus-kasus: Upaya Tak-teraga Sebagai Kearifan Lokal}

Dalam merespon bencana, terdapat bentuk bentuk tak-teraga yang memberikan fungsi bagi suatu kearifan lokal dalam menjalankannya. Bentuk bentuk ini dapat disebut sebagai "modal budaya" (atau modal sosial), seperti kelembagaan masyarakat, ketrampilan individu dan kolektif, pengetahuan masyarakat, nilai-nilai budaya positif, dan kapasitas-kapasitas sosio-budaya lain pada umumnya yang dapat menjadi "modal" dalam dan untuk merespon bencana di lingkungannya. Bentuk-bentuk ini menjadi dimensi sisi "penyedia" kearifan lokal yang memungkinkan bagi dikembangkannya suatu produk atau sistem upaya dan dihasilkannya keputusan untuk merespon bencana.

Dimensi kedua bentuk tak-teraga adalah sisi "penerima" terhadap sistem atau keputusan untuk merespon bencana, yaitu nilai nilai budaya dari masyarakat suatu lokalitas dalam "menerima" "sistem (dan keputusan)" yang dihasilkan oleh komunitas dan digunakan untuk menghadapi bencana. Dimensi ini adalah berupa kepatuhan, atau sikap-sikap yang sifatnya menerima keputusan, menjalankan produk atau sistem, atau hal-hal lain yang dijalankan masyarakat dalam merespon bencana.

\section{Kasus modal budaya merespon bencana}

Pada masyarakat di permukiman-permukiman adat atau tradisional yang (masih) memegang teguh adat yang kokoh, modal budaya sudah ada sejak lama dan "melembaga" dalam kehidupan masyarakatnya. Modal budaya sebagai suatu kearifan lokal berperan dalam merespon bencana secara "melembaga" dan mentradisi karena 
sudah "tertanam" lama pada masyarakat tersebut. Ilustrasi dapat diberikan oleh contohcontoh berikut.

Ammatoa-Kajang di Sulawesi, dikenal sebagai permukiman adat yang sudah lama berdiri dan teguh dengan adat-istiadatnya yang unik. Disebutkan bahwa permukiman Ammatoa Kajang (tidak hanya huniannya) adalah suatu ujud fisik dari budaya suatu masyarakat adat-tradisional (Osman, et.al; 2020). Osman dalam studinya menunjukkan melalui uraiannya bahwa norma-norma tradisi yang sudah berakar lama di Ammatoa Kajang menjadi dasar bagi masyarakat setempat dalam membangun permukimannya, menjalankan kegiatan bermukim, dan menjalankan kehidupannya secara lebih luas. Masyarakat Kajang secara konsisten merujuk dan mentaati suatu kerangka norma dan "panduan" hidup tak tertulis yang disebut "Pesan-pesan di Kajang" ("Pasang ri Kajang") yang berisi petuah-petuah, nasehat, instruksi, aturan-aturan kongkrit, bahkan sampai dengan prosedur bagaimana manusia harus menempatkan dirinya di dalam kosmos makro dan mikro. Seluruh aspek norma ini menjadi modal budaya yang dilaksanakan di Kajang secara mentradisi, yang diperkuat oleh modal budaya lain berupa nilai-nilai untuk melestarikannya. Modal budaya ini menjadi kerangka di dalam penataan permukiman Kajang, yaitu: penataan permukiman, cara berhubungan harmonis dengan alam dan Tuhan, perlindungan hutan, penggunaan jalan, penggunaan kendaraan, cara membangun rumah, dan sebagainya.

Dalam kaitan dengan antisipasi bencana, memang tidak secara eksplisit terdapat proses dan aturan-aturan terkait yang dibuat sebagai panduannya, tetapi norma-norma di atas memiliki implikasi yang jelas dalam mengantisipasi bencana. Contohnya, salah satu aturan penataan permukiman dan berkegiatan adalah adanya sistem zonasi yang menghasilkan zona-zona Hutan Pusaka, Hutan Kemasyarakatan, Hutan Rakyat, lokasi untuk hunian, serta apa yang boleh dilakukan dan tidak boleh dilakukan di dalam masing-masing zona. Aturan-aturan ini bahkan sampai dengan aturan tentang pembagian jalan menurut jalur yang boleh dipakai jalan kaki dan bagian yang dilalui hewan. Aturan-aturan ini memiliki manfaat yang langsung terhadap antisipasi bencana longsor karena semangat pelestarian alamnya.

Adanya sistem zonasi, yang menghasilkan antara lain zona Hutan Pusaka yang merupakan suatu aturan penataan permukiman, juga memiliki fungsi untuk mengatur hubungan manusia dengan alam dan menjaga kelestarian alam, dan menjaga sumber daya alam untuk manusia. Paralel dengan ini, terdapat panduan yang mengatur pemanfaatan hasil Hutan Pusaka tersebut yang bersifat kongkrit, seperti dibolehkannya masyarakat mengambil hasil hutan dari Hutan Pusaka apabila memiliki ijin dari AmmaToa (pemimpin adat). Zona hutan berikutnya adalah "Hutan Kemasyarakatan", yaitu hutan yang pohonnya boleh ditebang, tetapi dengan ketentuan bahwa yang akan menebang pohon sebelumnya harus menanam terlebih dahulu bibit yang sama pada titik persis dekat pohon yang akan ditebang. Setelah ini, terdapat "Hutan Rakyat", yaitu zona hutan yang boleh digunakan sebagai lahan pertanian, serta area hunian dengan syaratsyarat dan aturan di dalamnya. Karifan lokal ini merupakan hasil dari modal budaya di Ammatoa-Kajang berupa aturan-aturan yang mengacu pada filosofi hidup yang terdapat 
pada "Pasang ri Kajang", yang jelas sekali berangkat dari konsep pelestarian dan hidup manusia yang harmonis dengan alam dan juga memiliki aspek tujuan dan fungsi merespon bencana, khususnya bencana banjir dan longsor.

Modal budaya seperti di Ammatoa Kajang tersebut juga dimiliki secara mentradisi oleh banyak permukiman adat/tradisional lain, dan berangkat dari suatu filosofi hidup yang memiliki nilai budaya tinggi, seperti prinsip Tri Tangtu di permukiman adat/tradisional Jawa Barat yang antara lain berwujud pembagian zona permukiman dan aturan-aturannya (Belgawan, et.al, 2011). Kemudian dikenal pula filosofi “Adat Basandi Syara', Syara' Basandi Kitabullah” di Sumatera Barat yang diturunkan menjadi kelembagaan mitigasi bencana berbasis Nagari di suatu desa di Kabupaten Agam (Rozi, 2017). Contoh lain adalah filosofi "Tri Hita Kirana" (melaksanakan integrasi antara Parahyangan, Pawongan, dan Palemahan) dalam menjalankan kehidupan masyarakat tradisional di Bali yang salah satu unsurnya, yaitu "Palemahan", mengatur hubungan antara manusia dan lingkungan alam serta lingkungan bujatan (Dwijendra, 2003). Pengejawantahan dari filosofi-filosofi hidup ini adalah pelembagaan dari berbagai aspek kapasitas masyarakat yang menjadi modal budaya sebagai kearifan lokal, yaitu pengetahuan, aturan, sistem hukum (adat), ketrampilan, dan nilai-nilai yang mengatur aksi dan tindakan manusia, termasuk dalam menjalin hubungannya dengan alam, yang juga berimplikasi pada respon masyarakat terhadap bencana.

\section{Budaya Tabu}

Salah satu sikap budaya terhadap alam yang dapat memiliki fungsi dan peran dalam menghadapi bencana adalah kepatuhan dan/atau tabu. Dalam konteks hubungan antara "penyedia"dan "penerima (yang menjalankan)" keputusan, kepatuhan dan/atau tabu terhadap suatu hal dapat didudukan sebagai dimensi budaya yang berada pada sisi "penerima" untuk "berpartisipasi" merespon kebencanaan.

Contoh dari partisipasi melalui budaya tabu dalam merespon bencana adalah pada kasus masyarakat di Desa Bojongkoneng di pinggiran Kabupaten Bogor yang pernah dilanda bencana longsor. Budaya tabu memberikan nilai kepatuhan untuk tidak menebang dan merusak pohon di hutan dan tidak menambang batu, serta percaya tentang akibat-akibatnya apabila tabu itu dilanggar (dalam penelitian Raharja, et.al; 2018). Budaya ini berangkat dari pengalaman kejadian longsor sebelumnya sehingga masyarakat yang bersangkutan takut terhadap akibat-akibatnya apabila "tabu" ini dilanggar. Pada sisi lain, kasus Bojongkoneng ini menunjukkan bahwa budaya tabu terbentuk karena adanya kepercayaan (terhadap tabu) yang muncul dari pengalaman.

Contoh lain budaya tabu yang muncul karena adanya pengalaman terlebih dahulu, dan berperan dalam memitigasi bencana longsor, ditunjukkan oleh kasus di hutan Repong Damar, Kecamatan Way Krui, Kabupaten Pesisir Barat, Lampung, seperti diuraikan oleh Herlina, et.al (2020). Pelestarian Hutan Repong Damar telah lama dilakukan oleh masyarakat Krui di Lampung yang telah menghasilkan keberlanjutan produksi damar (dan kayu dari pohon damar) untuk penghasilan dan kesejahteraan 
petani penanam pohon damar, keseimbangan ekologis, dan hubungan yang harmonis antara lingkungan alam dan manusia. Pelestarian ini dijaga oleh budaya adat berbentuk tabu yang melarang mengeksploitasi hutan secara berlebihan, adanya kepercayaan bahwa pelanggaran terhadap tabu akan menyebabkan penderitaan dan hukuman sosial bagi masyarakat yang melanggar budaya tabu. Pelestarian juga dilakukan melalui penanaman pohon damar secara turun-temurun, selain karena hasil dari pohon damar dapat memberikan kesejahteraan, juga karena pengalaman dan pengetahuan bahwa keberadaan hutan damar yang lestari dapat mencegah longsor.

Namun demikian, terdapat budaya tabu yang tidak terkait langsung dengan pengalaman atau pengetahuan sebelumnya tetapi tumbuh karena adanya ketaatan secara konsisten dan mentradisi dalam suatu masyarakat lokal, tanpa masyarakat bertanya tentang penjelasannya. Masyarakat di permukiman Kampung Naga (GarutTasikmalaya), Kampung Baduy (Banten), dan beberapa desa adat atau tradisional lain, misalnya, memiliki budaya tabu untuk berbagai hal. Salah satu budaya tabu ini terkait dengan larangan melakukan sesuatu di permukiman, yang di antara manfaatnya adalah untuk pencegahan bencana. Tabu tersebut dikaitkan dengan adanya sistem zonasi di permukiman mereka, yang di antaranya memiliki zona yang dinamakan "Hutan Larangan".

Hutan Larangan adalah salah satu hasil pembagian zonasi permukiman menjadi beberapa zona yang memisahkan antara kawasan non-hunian dan kawasan hunian di lingkungan permukiman. Sementara itu, kawasan non-hunian masih terbagi lagi ke dalam beberapa zona kawasan dengan fungsi pelestarian sumber-daya air dan sumberdaya alam lain, yang dapat memiliki fungsi pencegahan bencana banjir dan longsor.

"Hutan Larangan" adalah salah satu zona non-hunian sebagai hasil dari sistem zonasi tersebut yang terdapat pada banyak permukiman adat atau tradisional di Jawa Barat. Hutan larangan adalah bagian zona non-hunian berupa kawasan hutan di dalam lingkungan permukiman adat/tradisional yang harus dilestarikan, tidak boleh digunakan, dan/atau diambil hasilnya. Hutan Larangan adalah salah satu dari tiga jenis zona hutan di permukiman-permukiman adat/tradisional di Jawa Barat dengan pembagian kawasan hutan (non-hunian) menurut filosofi Tri-Tangtu, yaitu Hutan Larangan (Leuweung Tutupan), Hutan Titipan (Leuweung Titipan), dan Hutan Garapan (Leuweung Garapan). Hutan Larangan biasanya terdapat di bagian paling atas dari daerah perbukitan lingkungan permukiman. Dengan demikian, keberadaan Hutan Larangan yang dijaga oleh aturan tentang larangan penggunaannya memiliki peran ekologis untuk kelestarian air, sumber daya alam lain, dan pencegahan bencana banjir atau longsor.

Melalui sistem zonasi, juga terdapat pengaturan dalam beraktivitas di dalam setiap zona. Pada lingkup yang lebih spesifik, juga terdapat pengaturan-pengaturan dalam setiap zona tentang yang boleh dan tidak boleh dilakukan dalam beraktifitas, termasuk dalam Hutan Larangan. Pengaturan dan aturan yang telah berjalan lama secara mentradisi ini menghasilkan kepatuhan terhadapnya secara mentradisi juga, yang tidak terlepas dari adanya budaya tabu (pamali - Sunda) yang mentradisi dan ditaati oleh penduduk setempat. Istilah pamali sendiri berkonotasi larangan atau "tidak baik untuk 
dilakukan" untuk suatu kegiatan, yang biasanya tanpa penjelasan tentang akibat-akibat kongkritnya.

Contoh lain adalah budaya pamali dalam pemanfaatan air di Kampung Kuta, Ciamis, di dalam penelitian Suyatman (2018). Diuraikan bahwa masyarakat dilarang (melalui kepercayaan pamali) untuk menggali sumur sendiri yang bertujuan untuk menjaga kondisi air bawah tanah agar selalu baik. Sedang air yang digunakan untuk upacara adat ritual nyipuh bersumber dari air yang ada di dalam Hutan Keramat (atau Hutan Larangan). Sumberdaya air yang ada di dalam hutan Keramat tidak dimanfaatkan untuk keperluan sehari-hari karena terdapat pamali. Adanya budaya pamali dalam pengelolaan Hutan Keramat terbukti menjaga kelestarian ekosistem di dalamnya sehingga sumberdaya air yang ada di dalamnya juga terjaga dengan baik.

Dalam beberapa penelitian yang dirujuk di atas telah diuraikan tentang norma beraktivitas terkait sistem zonasi dan kepatuhan masyarakat yang menjalankan produk budaya tersebut secara mentradisi dan konsisten (menjalankan kebiasaan, patuh terhadap aturan, patuh terhadap tabu, dan lain sebagainya). Namun demikian, penelitian-penelitian tersebut tidak banyak memberikan penjelasan tentang bagaimana cara menanamkan atau proses menginternalisasi, budaya terkait terhadap masyarakatnya.

Juga tidak ada analisis dan penjelasan bagaimana menjalankan proses proses untuk mengembangkan dan menghasilkan berbagai instrumen pelaksanaan budaya tersebut (misal: mengembangkan aturan zonasi di permukiman adat, mengembangkan kebiasaan-kebiasaan, menciptakan tabu, mengembangkan "organisasi” yang menjalankan fungsi-fungsi mengelola respon terhadap bencana, dan lain sebagainya).

Tidak mudah menggali pengetahuan aspek-aspek proses internalisasi dan pengembangan instrumen dari kearifan-kearifan lokal di atas untuk menjadi pembelajaran bagi lingkup yang lebih luas karena pengetahuan tentang aspek "tak teraga" tersebut pada umumnya bersifat embedded. Ini mungkin yang menjadi sebab penelitian yang mengkaji aspek tak teraga (proses-proses) upaya merespon bencana umumnya lebih bersifat deskriptif di dalam kajian-kajiannya, setidaknya ditunjukkan oleh rujukan-rujukan di atas.

Memang, suatu upaya merespon bencana dari kelompok yang bersifat "tak teraga" tersebut memiliki aspek yang "teraga", yang kandungan pengetahuannya dapat bersifat eksplisit sehingga penelitiannya dapat bersifat analitikal dan pengetahuan yang terkandung di dalam upaya tersebut dapat disingkap. Sebagai conto, dalam kasus Hutan Repong Damar di atas, logika dari kebiasaan menanam pohon damar bagi pencegahan bencana longsor relatif mudah disingkap karena sifatnya "teraga" dan dapat dijelaskan oleh pengetahuan yang ada. Walaupun demikian, fungsi ekologis menanam jenis pohon tertentu ini perlu dibedakan dari pengetahuan tentang membangun kebiasaan menanamnya. Aspek paling penting yang perlu dipelajari dari contoh kearifan lokal kebencanaan yang tak teraga ini justeru terletak pada proses-proses internalisasi pada masyarakat lokal terkait untuk menjalankan kebiasaan menanam tersebut sebagai suatu tradisi. 


\section{Kasus: Dimensi Teknologi}

Teknologi adalah "produk" sebagai suatu kearifan lokal yang dihasilkan oleh suatu bentuk kearifan lokal yang lain, yaitu "modal budaya" (telah diuraikan sebelumnya). Teknologi adalah satu bentuk kearifan lokal yang bersifat kongkrit, teraga, dan langsung di dalam merespon bencana. Banyak teknologi "lama"/tradisional yang dapat dikategorikan sebagai kearifan lokal di dalam merespon bencana karena memiliki keunikan yang telah mengakar dalam budaya masyarakat penciptanya dan memiliki kemampuan untuk menyelesaikan tantangan kebencanaan serta memiliki nilainilai kearifan di dalam pembentukan dan penggunaannya.

Teknologi bangunan adalah suatu kearifan lokal dalam merespon bencana yang paling banyak dikaji terutama dalam merespon gempa walaupun teknologi juga banyak penerapannya pada berbagai obyek atau konteks kebencanaan lain, seperti untuk pengendalian banjir dan longsor. Teknologi bangunan dalam merespons gempa sebagai kearifan lokal yang tradisional, baik yang berasal dari dalam maupun dari luar Nusantara, sering dibahas dan dipelajari dalam kaitan dengan pembelajaran untuk masa kini. Kajian-kajiannya tidak berhenti pada kajian deskriptif tetapi bersifat analitikal, yaitu membedah sehingga teknologinya berhasil dikenali. Beberapa kasus berikut mengilustrasikan beberapa penelitian semacam ini.

Triyadi, et.al (2009) menunjukkan bahwa respon terhadap gempa pada bangunan-bangunan tradisional/adat atau vernakular di Nusantara bersifat konseptual, dan terdapat pada berbagai aspek dari skema (rancangan) bangunannya: Studinya menganalisis bahwa denah rumah berbentuk kotak dan simetris serta pembagian ruangan yang teratur memiliki fungsi dalam memberikan kekakuan yang seimbang pada unsur-unsur bangunan apabila terjadi gempa. Kemudian struktur bangunannya yang merupakan susunan terintegrasi antara tiang lantai (tiang kolong bangunan), tiang bangunan di atasnya, dan rangka-rangka dinding yang kaku, serta sambungansambungannya yang memudahkan bergerak secara fleksibel bila terjadi gempa, dapat menghindari keruntuhan. Demikian pula, karena material bangunannya adalah kayu, maka bangunan menjadi ringan dan lentur yang juga menjadikan bangunan vernakular responsif terhadap gempa. Sistem dan skema bangunan yang menerapkan teknologi tahan gempa ini ada yang susunannya relatif sederhana seperti bangunan-bangunan rumah tinggal vernakular di Jawa Barat; yang relatif "canggih" seperti rumah joglo dengan sistem tumpuan dan sistem struktur atapnya; dan yang canggih dan rumit seperti rumah tradisional Nias, rumah tradisional Batak, atau rumah tradisional Minang.

Hasil penelitian lain juga telah membedah dan menunjukkan bahwa pada rumah joglo dan banyak rumah tradisional lainnya di Nusantara, pondasi umpak yang menerima beban dari tiang di atasnya adalah salah satu unsur bangunan yang menjadi bagian penting terkait responnya terhadap gempa. Hubungan antara pondasi umpak dan tiang di atasnya yang tidak saling mengikat karena tiang tidak tertanam membuat bangunan bisa bergeser apabila terjadi gempa sehingga tidak membuat bangunan runtuh karena gaya gempa direduksi oleh gaya geser, seperti contoh hubungan antara pondasi umpak dengan tiang soko guru dari bangunan joglo Yogya (Maer, 2008). Kearifan lokal 
dari sistem struktur rumah joglo ini juga meliputi peran dari stuktur bagian atas/atap (berupa susunan sunduk, kili, santen, pengerat, blandar, dan tumpang sari) yang memungkinkan soko guru yang menopangnya bergeser seperti goyangan lentur cantilever (balok satu tumpuan).

Prinsip serupa juga digali oleh penelitian dari Lukmantarna (2012) pada bangunan tradisional Nias. Pondasi umpak menjadi tumpuan tiang-tiang di atasnya tanpa tiang tertanam pada umpak, sehingga pondasi umpak menjadi semacam friction damper (peredam) terhadap gaya gempa karena antara tiang dan pondasi umpak akan terjadi geseran ketika terjadi gempa. Pada kolong rumah, terdapat bracing (pengaku) yang menstabilkan bagian bawah bangunan agar pergeseran bangunan tidak memberikan gaya gempa yang terlalu besar pada struktur bangunan di atasnya ketika tiang di atas umpak bergeser, sehingga bagian atas bangunan tidak akan rusak ketika terjadi gempa. Apabila sesudah gempa terjadi pergeseran bangunan, bangunan bisa diangkat dan didudukkan kembali pada posisinya semula dengan upaya bersama.

Contoh-contoh kearifan teknologi bangunan (yang) tahan gempa dari kekayaan Nusantara di atas menunjukkan keberfungsiannya di dalam konteksnya masing-masing. Contoh-contoh teknologi ini tidak dapat begitu saja diterapkan dalam konteks yang lain, misalnya untuk bangunan besar dengan bahan bangunan produk modern, tanpa pengetahuan yang terkandung di dalam teknologi lokal tersebut, yang kebanyakan bersifat embedded, dijadikan pengetahuan eksplisit agar dapat dimengerti. Namun, uraian dan penjelasan tentang perilaku teknologi dari kasus-kasus di atas, yang merujuk pada berbagai hasil studi/penelitian, menunjukkan bahwa para penelitinya dapat mengeksplikasikan atau mengeksplisitkan teknologi-teknologi lama yang pengetahuannya bersifat embedded menjadi eksplisit sehingga logika dan sistimatika dari teknologi-teknologi tersebut dapat diketahui seperti terurai sebelumnya.

Selain itu, karena teknologi bangunan berkaitan dengan hal-hal yang teraga dan terukur, dan pengetahuannya telah berkembang, pengetahuan yang berasal dari kearifan lokal tersebut telah banyak yang dikodifikasi sehingga telah menjadi pengetahuan eksplisit yang lebih umum yang memungkinkan teknologi bangunan tahan gempa yang berasal dari kearifan lokal dikonversi untuk konteks kekinian yang lebih luas. Contoh berikut menunjukkan penerapan teknologi bangunan tahan gempa yang berasal dari mengeksplisitkan pengetahuan yang terdapat dari kearifan lokal lama.

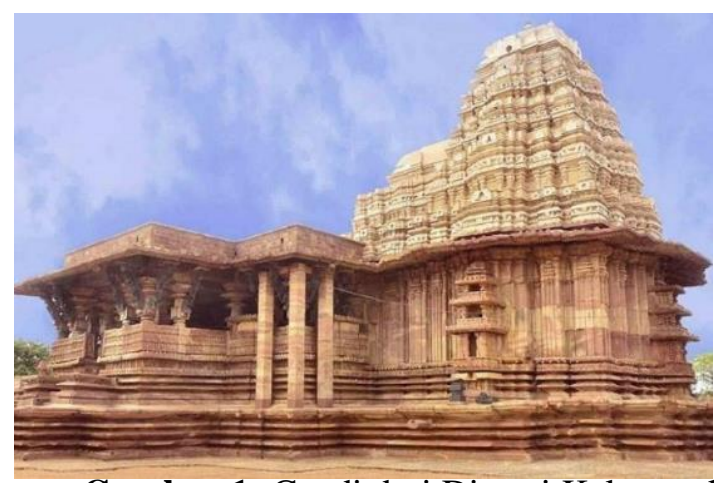

Gambar 1: Candi dari Dinasti Kakatya di

India(https://www.thenewsminute.com/article/800-yr-old-kakatiyaera-temple-warangal-nominated-unesco-world-heritage-tag-97857). 
Di India, yaitu di daerah Hyderabad, banyak bangunan sekarang menggunakan teknologi pondasi yang diwariskan oleh kearifan lokal sistem konstruksi bangunan lama dari Dinasti Kakatya untuk mengurangi dampak gempa (New Indian Express, 2018). Sitem konstruksi lama ini adalah berupa teknik pondasi "Kotak Pasir" yang membuat bangunan dapat merespon gempa untuk menghindari dampak kerusakan yang ditimbulkannya. Awalnya, teknik ini digunakan di dalam membangun candi-candi dalam masa dinasti tersebut dan terbukti tidak terganggu oleh kerusakan akibat gempagempa yang telah berlangsung dalam ratusan tahun keberadaannya. Teknik ini unik karena pembangunan pondasi dilakukan dengan menggali lobang untuk pit pondasi, mengisi pit dengan bahan terdiri dari campuran pasir kapur, perekat alami, dan buah myrobalan, sebelum pendirian pondasi, dan kemudian mendirikan bangunan di atasnya. Landasan dari pasir kapur tadi berfungsi sebagai "bantal" yang meredam kekuatan dari gempa. Teknik tersebut dikembangkan pada awal abad 12 di bawah Maharaja Rudradveva dari dinasti Kakatiya, dan penggunaannya menyebar ke mana-mana, digunakan di ribuan bangunan dan candi dari masa itu. Para ahli masa kini di India telah meneliti dan mengatakan bahwa teknik ini layak digunakan di bangunan-bangunan modern yang tidak terlalu tinggi. Keyakinan ini telah dirumuskan untuk aplikasi masa kini karena para ahli berhasil me-retrieve (menyingkap) pengetahuan yang terkandung di dalam teknologi kearifan lokal lama tersebut menjadi suatu pengetahuan yang bersifat eksplisit dalam bentuk prinsip-prinsip dan formula dari teknik pondasi ini.

Contoh lain adalah Menara Sky Tree di Tokyo, suatu bangunan setinggi 634 meter yang merupakan bangunan tertinggi kedua di dunia, yang selesai dibangun pada tahun 2012. Bangunan ini adalah bangunan menara pemancar televisi dan radio yang besar serta memiliki berbagai ruangan, termasuk ruang besar untuk observasi di lantai teratas, sering dikunjungi turis, dan menerima turis sebanyak jutaan setiap tahunnya. Sistem strukturnya dikatakan dapat meredam gaya gempa sampai dengan 50\% (Nakata, 2012), yang dirancang mengikuti kearifan lokal Jepang yang terdapat dalam teknologi sistem struktur menara pagoda lama yang disebut "Shinbashira", yang memiliki kemampuan menghindari dampak gempa yang sering melanda Jepang (Karlovic, 2017).
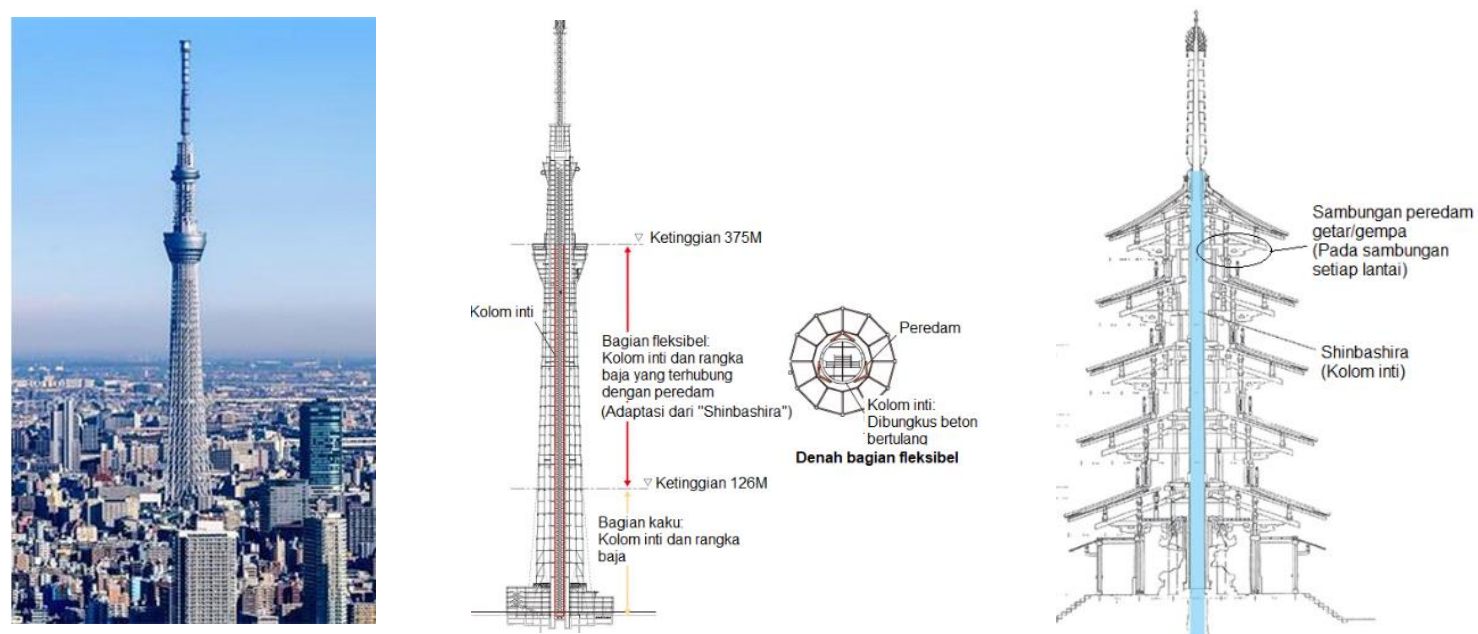

Gambar 2: Menara Sky Tree dan Pagoda di Jepang: Penerapan prinsip struktur pagoda kuno 
Jepang, negara yang sangat sering dilanda gempa, memiliki ribuan bangunan pagoda, bahkan yang ukurannya tinggi. Selama kurang lebih 1400 tahun keberadaannya, hampir tidak ada pagoda yang rubuh oleh gempa, kecuali hanya 2 pagoda. Sistem dan teknik struktur tradisional Shinbashiara tersebut merupakan kearifan lokal Jepang yang telah berperan untuk menghindarkan dampak gempa terhadap bangunan-bangunan pagoda. Keunikan struktur pagoda yang merupakan pengetahuan lokal perancangan bangunan di Jepang yang sudah mentradisi terletak pada adanya tiang utama di tengah (inti) pagoda yang disebut "Shinbashira". Tiang ini ibarat tulang punggung manusia, yang dapat melengkung secara lentur untuk menahan beban angin atau gempa, dan kembali tegak ketika gaya angin atau gempa tiada. Fungsi Shinbashira ini dikombinasi dengan dua aspek struktural lain. Pertama, pagoda-pagoda di Jepang biasanya tersusun dari lima lantai yang tersusun dari sistem strukturnya masing-masing yang terbuat dari kayu, yang menambah kemampuan lengkung Shinbashira dan kelenturannya. Kedua, sambungan antar batang kayu pada struktur setiap lantai tidak "dipaku" tetapi dibuat dari sambungan yang dapat bergeser sehingga energi gempa tidak berjalan dari bawah ke atas. Dengan demikian, terjadi efek goyangan seperti ular apabila terjadi gempa, bukan keruntuhan bangunan. Prinsip inilah, sebagai pengetahuan yang tertanam (embedded) pada sistem struktur Shinbashira sebagai suatu kearifanl lokal, yang berhasil di"eksplisitkan" sehingga memungkinkan diadaptasi pada bangunan modern yang konteks dan kondisinya berbeda dari pagoda, yaitu bangunan Sky Tree yang tingginya puluhan kali bangunan pagoda tradisional.

\section{SIMPULAN}

Kearifan lokal sudah terbukti banyak yang berhasil mengatasi berbagai bencana, baik secara langsung maupun secara tidak langsung. Bentuk-bentuk kearifan lokal di dalam merespon bencana dan kebencanaan dapat berupa: teknologi, aturan yang melembaga, kepatuhan, organisasi, tindakan, atau kebiasaan. Setiap bentuk upaya dari kearifan lokal di dalam merespon bencana memiliki kerangka pengetahuan sendiri. Kerangka pengetahuan dari setiap upaya merespon bencana ini dapat dipelajari agar lingkupnya yang bersifat lokal dapat ditransformasi menjadi kerangka pengetahuan yang berlaku untuk konteks umum yang berlaku luas. Namun demikian, tidak setiap pengetahuan yang terkandung dalam setiap upaya dalam kearifan lokal mudah untuk disingkap dan dikodifikasi untuk kepentingan penerapan yang lebih luas, tergantung dari bentuk upaya merespon bencana dan pengetahuan yang dikandungnya, apakah berbentuk relatif eksplisit, implisit/tacit, atau embedded. Dari berbagai aspek atau jenis upaya merespon bencana, jenis upaya yang teraga cenderung mengandung pengetahuan dalam golongan yang eksplisit sehingga relatif mudah untuk disingkap dan ditransformasi menjadi pengetahuan pencegahan bencana yang dapat berlaku untuk konteks yang luas dan kekinian.

Berdasarkan penelitian-penelitian kasus-kasus yang dirujuk untuk makalah ini, hasil penelitian kasus-kasus terkait teknologi (dalam hal ini teknologi bangunan tahan gempa) telah diuraikan dan dijelaskan oleh para penelitinya sampai pada pembahasan 
struktur dan logika dari teknologi yang dikaji. Pembahasan para peneliti/penulis terhadap kasus-kasus teknologi ini bersifat analitikal, yaitu membedah teknologi yang bersangkutan. Ini menunjukkan bahwa kearifan-kearifan lokal berupa teknologi bangunan tersebut mengandung pengetahuan yang cukup eksplisit sehingga dapat disingkap dan diungkapkan dengan jelas oleh para penulis/peneliti dari rujukan kasus. Bahkan, hasil penyingkapan pengetahuan teknologi yang merespon bencana dari kearifan lokal dapat ditransformasi dan diadaptasi menjadi pengetahuan teknologi untuk kepentingan masa kini yang lebih luas, seperti yang dicontohkan oleh pondasi kotak pasir dari candi-candi peninggalan Dinasti Kakatiya di India dan sistem struktur pagoda Shinbashira yang diadaptasi untuk bangunan tertinggi kedua di dunia, yaitu Menara Sky Tree di Tokyo, Jepang.

Sementara itu, kearifan lokal kebencanaan yang berbentuk non-teknologi yang tak teraga seperti tabu, kebiasaan, pelaksanaan mitos, organisasi, aturan berbuat, dan sebagainya tidak memiliki pengetahuan yang bersifat eksplisit yang lengkap untuk dapat disingkap, ditransformasi, dan diadaptasi dengan mudah bagi konteks yang lebih luas dan kekinian. Para penulis/peneliti yang meneliti dan membahas kasus-kasus dalam kategori non-teknologi ini cenderung menyampaikan keberadaan kearifan lokal dari hasil penelitiannya ini secara deskriptif, tidak bersifat "membedah" secara analitikal upaya-upaya dari kelompok kearifan lokal kebencanaan ini.

Hal yang sulit di dalam menyingkap pengetahuan yang terkandung dalam kearifan lokal kebencanaan yang tak teraga ini terutama adalah tentang proses-proses membangun kebiasaan, menumbuhkan kepercayaan pada mitos atau tabu, atau menanamkan kemauan menjalankan aturan untuk merespon bencana. Juga sulit disingkap pengetahuannya adalah proses-proses mengembangkan suatu "instrumen" untuk merespon bencana (organisasi, aturan, kebiasaan, tabu, dan sebagainya) dan mengapa instrumennya demikian. Hal-hal ini justeru merupakan aspek kearifan lokal tak teraga yang penting untuk menjadi pelajaran bagi perluasan konteks pelaksanaannya. Bagaimana cara untuk membangun, mengembangkan, dan mengaplikasikan aspek tak teraga tersebut dalam mengatasi bencana perlu disingkap menjadi pengetahuan eksplisit bagi keperluan masa kini dan lingkup yang lebih luas yang berbeda dari konteks lokalitas tempat beradanya kearifan lokal tersebut.

Ini berarti, pengetahuan tentang cara menginternalisasi berbagai aspek kearifan lokal merespon bencana yang tak teraga tersebut (kebiasaan, kepatuhan, organisasi, dan sebagainya), yang umumnya bersifat embedded, perlu dibuat eksplisit dan menjadi pengetahuan yang sistematikanya tersusun agar dapat diadaptasi dan diadopsi untuk konteks yang lebih luas dan kekinian. Akan tetapi, pengetahuan sebagai (dan dari) suatu kearifan lokal, tidak begitu saja mudah dipelajari karena sifat pengetahuannya yang tidak semuanya mudah dikodifikasi untuk menjadi pengetahuan eksplisit, agar dapat diterapkan secara umum. 


\section{DAFTAR PUSTAKA}

Belgawan, Ismet; et.al; Arsitektur Rumah dan Permukiman Tradisional di Jawa Barat; Dinas Pariwisata dan Kebudayaan, Propinsi Jawa Barat, Bandung

Chugh, Ritesh (2015); "Do Australian Universities Encourage Tacit Knowledge

Transfer?"; Proceedings of the 7th International Joint Conference on Knowledge

Discovery, Knowledge Engineering and Knowledge Management. pp. 128-135.

Dwijendra, Ngakan Ketut Acwin (2003); "Perumahan dan Permukiman Tradisional

Bali"; Jurnal Permukiman Natah, Vol. 1, No. 1, 2003; pp 8-24

Herlina, Meri; Dewi Liesnoor Setyowati; Juhadi (2020); "Local Wisdom of Repong

Damar for Landslide Mitigation in Way Krui Subdistrict, Pesisir Barat Regency,

Lampung"; Makalah Konperensi;

https://www.researchgate.net/publication/338647156

Karlovic, Alen (2017); Shinbashira - "Pagoda's Exceptional Earthquake Resistance";

diakses pada https://medium.com/konsiteo -today/shinbashira-pagodas-

exceptional-earthquake-resistance

Lumantarna dan Pudjisuryadi (2012); "Learning from Local Wisdom: Friction Damper in Traditional Building", Civil Engineering Dimension, Vol. 14, No. 3, December 2012 (Special Edition), 190-195

Maer, Bisatya W (2008); "Respon Pendopo Joglo Yogyakarta terhadap Getaran Gempa Bumi”; Jurnal Dimensi Teknik Arsitektur, Vol. 36, No. 1, Juli 2008, hal 1 - 9

Mitchell, B., Bobby Setiawan, dan DH Rahmi, (2004); Pengelolaan Sumberdaya dan Lingkungan; Gajah Mada University Press, Yogya

Nakata, Hiroko (2012); "Tokyo Sky Tree opener looms large", Japan Times, 21

February 2012, p. 3.

New Indian Express (25 Oktober 2018), "Did Kakatiya Rulers Hold the Secret to Earthquake-Proof Buildings?", diakses pada https://www.newindianexpress.com/cities/hyderabad/2018/oct/25/ did-kakatiyarulers-hold-the-secret-to-earthquake-proof-buildings-1889809.html

Osman, Wiwik Wahidah; Shirly Wunas; Mimi Arifin; dan Ria Wikantari (2020); “The Spatial Patterns of Settlement Plateau of the Ammatoa Kajang: Reflection of Local Wisdom", International Journal of Civil Engineering and Technology (IJCIET), Volume 11, Issue 1, January 2020, pp. 199-208; Tersedia daring pada http://www.iaeme.com/ijciet/issues.asp? JType=IJCIET\&VType=11\&IType $=1$

Raharja, Randi; Faisal Grahadi Wibowo; Riski Vitria Ningsih; dan Sari Viciawati Machdum (2018); "Peran Kearifan Lokal dalam Mitigasi Bencana: Studi Masyarakat dalam Menghadapi Bencana Longsor di Desa Bojongkoneng, Kabupaten Bogor”, Jurnal Dialog Penanggulangan Bencana, Vol. 7, Nomor 2, 2016

Rozi, Syafwan (2017); “Local Wisdom and Natural Disaster in West Sumatera," el Harakah Vol.19 No.1 Tahun 2017

Suyatman, Ujang (2018); “Teologi Lingkungan dalam Kearifan Lokal Masyarakat Sunda,” Jurnal al-Tsaqafa Volume 15, No. 01, Juli 2018 
Triyadi, Sugeng; Iwan Sudradjat; Andi Harapan (2009); "Kearifan Lokal pada

Bangunan Rumah Vernakular di Bengkulu dalam Merespon Gempa: Studi Kasus

Rumah Vernakular di Desa Duku Ulu," Seminar Nasional Kearifan Lokal dalam

Perencanaan dan Perancangan Lingkungan Binaan; 7 Agustus 2009, Universitas

Merdeka, Malang

Wayne, Jonathan (2017); The Difference between Belief and Knowledge,

https://medium.com/ perspectivepublications/the-difference-between-belief-and-

knowledge-cb909520a265

Wellman, Jerry L (2009); Organizational Learning: How Companies and Institutions

Manage and Apply Knowledge; Palgrave Macmillan, New York

\section{HASIL DISKUSI}

\section{Pertanyaan}

1. Arif Budiman (MAN 1 Jakarta)

Bagaimana caranya agar kebudayaan Jawa itu tidak selalu diidentikkan dengan

mistisisme, musyrik, dan sebagainya, dan kita dapat menerapkannya untuk manfaat hari ini?

\section{Jawaban}

1. Hasil kebudayaan akan dihargai apabila digunakan. Karena digunakan maka artinya dihargai. Penggunaan ini harus didasarkan kepada suatu pengetahuan tentang manfaat dan kerugiannya. Misal buka sepatu ketika masuk rumah, sehingga dibuatlah tempat sepatu khusus, bukan di teras sehingga orang selalu menggunakannya ketika masuk ke suatu rumah. Intinya, untuk mengharagai kita harus tahu manfaatnya. Bagaimana sampai kepada pengetahuan tersebut maka harus membuka makna inti rasionalitasnya dan manfaatnya. Hal inilah yang juga berlaku dalam memanfaatkan dan menggunakan kearifan lokal. Proses mengungkap pengetahuan itu, agar rasionalitas dan manfaatnya dipahami, merupakan proses yang tidak pendek tetapi panjang. Dalam proses ini dicari prinsip, rumus, dan sebagainya dari pengetahuan yang terkait dengan manfaatnya tersebut. Dalam kaitan ini, rasionalitasnya diangkat/disingkap sehingga dapat dipahami dan akhirnya diterima. 